Part of Journal of Research of the National Bureau of Standards, Volume 18, June 1937

\title{
COMPRESSIBILITY OF FUSED-QUARTZ GLASS AT ATMOSPHERIC PRESSURE
}

\author{
By Walter B. Emerson
}

\section{ABSTRACT}

The compressibility of fused-quartz glass was determined with sufficient accuracy to establish the required corrections for change of length with change of pressure of the fused-quartz glass étalons used in a Fabry-Perot interferometer to evaluate the indices of refraction of air for converting standards of wave length in air to their value in vacuo. Compressibility determinations were made for the same changes of pressure that were used for index measurements; namely, from vacuum to atmospheric pressures.

Determination of the compressibility of fused-quartz glass was made by interferometric comparison of the relative change in length of end gages of fused quartz and stainless steel.

Values for the compressibility of both fused quartz and stainless steel were also determined by a direct method which depended upon the relative change in length of a closed tube and a solid gage of the same material. By this method the compressibilities of fused quartz and of a stainless steel were determined independently, thereby elinainating the existing uncertainty as to the compressibility of steel at atmospheric pressure obtained by extrapolation from much higher pressures and eliminating, also, the necessity for comparison of materials with great difference in thermal expansivity.

Relative values for fused quartz and stainless steel were also derived from comparative changes in length with pressure of tubes and gages of dissimilar materials.

The measurements gave the following values for longitudinal compressibility at 1 atmosphere pressure:

For fused-quartz glass $9.9 \times 10^{-7} \pm 5 \times 10^{-8}$ per atmosphere.

For a sample of stainless steel $₹ 3.1 \times 10^{-7}$ per atmosphere.

\section{CONTENTS}

I. Introduction

1. Compressibility of separator involved in index of air determinations

2. Required accuracy of index determinations and of compressibility corrections

3. Materials for separators _...

4. Status of values for compressibility; purpose of this investigation.

II. Methods for determining compressibility

1. Method 1.-Comparison of two gages of unlike materials.--

2. Method 2.-Comparison of a closed tube and gage of the same material

3. Method 3.-Comparison of a tube and gage of unlike materials 
III. Apparatus _._.

1. Gages, tubes, and interferometer plates $\ldots$

(a) End gages, tube, and plates of fused quartz $\ldots . . .690$

(b) End gages and tube of steel; plates of fused quartz $-\quad 691$

2. Temperature-control apparatus _

3. Air pump

4. Interferometric measuring apparatus

IV. Experimental procedure and results

1. Preliminary measurements

(a) Comparison of two fused-quartz gages _........ 693

(b) Comparison of a fused-quartz gage with steel gages_- 694

(c) Effect of change of pressure upon temperatures within the chamber

(d) Cooling curves of steel gages

(e) Time required to establish thermal equilibrium within the constant-temperature chamber.....-

2. Final measurements
(a) Method 2.-Comparison of a closed tube and gage

(a) Method 2.-Comparison of a closed tube and gage
of the same material

(1) Fused-quartz tube and fused-quartz gage.-

(2) Steel tube and steel gage...-

(b) Method 3.-Comparison of a tube and gage of unlike

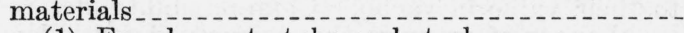

(1) Fused-quartz tube and steel gage

(2) Steel tube and fused-quartz gage..........

(c) Method 1.-Comparison of two gages of unlike materials

V. Summary of results

VII. Conclusion of results

\section{INTRODUCTION}

\section{COMPRESSIBILITY OF SEPARATOR INVOLVED IN INDEX OF AIR DETERMINATIONS}

Experimental procedure in the evaluation of the index of refraction of air by the Fabry-Perot interferometric method necessitates the determination of order of interference between surfaces of interferometer plates in air and in vacuum.

$$
\text { Refractive index of air, } n,=\frac{\text { number of waves in thickness }(t) \text { of air }}{\text { number of waves in thickness }(t) \text { of vacuum }}
$$

The distance between these surfaces is fixed by a separator of material, such as brass, steel, invar, or fused quartz. It is evident from the above relationship that any change in length of the separator during observations will affect, directly, the determined index value. Such change in length will be caused by change in pressure from vacuum to air pressure. This compressibility effect was recognized by Meggers and Peters, ${ }^{1}$ but for lack of reliable data, they made no corresponding corrections to their results. The required accuracy of index values determines the degree of accuracy to which this compressibility correction must be known.

\section{REQUIRED ACCURACY OF INDEX DETERMINATIONS AND OF COMPRESSIBILITY CORRECTIONS}

Correlation of length determinations made by interferometric methods in a vacuum with those at atmospheric pressure, at which

1 W. F. Meggers and C. G. Peters, Measurement of the refractive index of air for wave lengths from 2218 to 9000 A. Bul. BS 14, 723 (1918-1919) S327. 
our standard wave length is defined, requires an exact knowledge of the ratio of wave lengths of radiations in vacuum to their wave lengths in air; i. e., of the refractive indices of air. Wave lengths of many secondary standard radiations which were determined by comparison with the wave length of the primary standard red radiation of cadmium at atmospheric pressure are in agreement to within 1 or 2 units in the eighth significant figure. To transfer these air values to vacuum values with equal certainty requires that $(n-1)$ be known to $1 \times 10^{-8}$. Such accurate index determinations have not been made -present uncertainties are in the seventh decimal place. An index error of $1 \times 10^{-7}$ results in an error of 1 part per 10 million in vacuum wave lengths and consequently in lengths transferred to air values from vacuum measurements. To satisfy the demands of the metrologist, an accuracy of 1 part per 10 million, or $0.1 \mu$ per meter, should be attained.

Conversely, the atomic physicist demands a correspondingly accurate knowledge of the refractive index in the determination of optical dispersion for transference of his observations in air to basic vacuum values.

Measurement of indices with a certainty of $1 \times 10^{-7}$ requires that the compressibility correction of the interferometer étalon be known to one-half this value, $5 \times 10^{-8}$.

\section{MATERIALS FOR SEPARATORS}

Change in length of separators may be caused (1) by a change in pressure or (2) by a change of temperature during observations. Change in length with pressure, or compressibility, is a definite property of a material and, for a known pressure change, no error in index determinations should arise from this source, provided that its compressibility correction be known to the required accuracy. Change in length with temperature depends upon the thermal expansivity of the separator material. Fused quartz with an expansivity of $5 \times 10^{-7}$, as contrasted with $120 \times 10^{-7}$ for steel, is less affected by temperature change than other commonly used materials, with the exception of Invar. For the accuracy required in index determinations, error of length measurement should not exceed $0.005 \mu$ per decimeter of étalon, and this tolerance, in terms of temperature change, is equivalent to $0.1^{\circ} \mathrm{C}$ for fused quartz and $0.005^{\circ} \mathrm{C}$ for steel. Thus, the use of separators of low thermal expansivity eliminates the necessity for precision measurements of small differences in temperatures of $0.005^{\circ}$ C. With these separators, errors in index determinations resulting from changes in length with the small temperature differences encountered under carefully controlled temperature conditions can be made negligible. End gages of fused quartz have been made (method to be described by C. G. Peters and E. L. Robinson in a future NBS publication) with such perfection of planeness and parallelism of end surfaces that, when used as separators in a Fabry-Perot interferometer, measurable interference over a path of $250 \mathrm{~mm}$ resulted. Such separators of various lengths have been used for recent index of air determinations at this Bureau. 


\section{STATUS OF VALUES FOR COMPRESSIBILITY; PURPOSE OF THIS INVESTIGATION}

Since change of index with pressure and compressibility are simultaneous effects under the conditions of measurement, the relative effect of each is not readily determinable. Very few data are available upon which to base this compressibility correction when using metals, practically none are available for fused quartz, and those which are available were determined for pressures of many atmospheres. Question arises as to the exactness of such values when extrapolated to pressures in the range of 0 to 1 atmosphere. Available data give the longitudinal compressibility of some steel specimens as $2.0 \times 10^{-7}$, and any error in this value is transferred directly as an error to index values. Since indices are required to $1 \times 10^{-7}$, the compressiblity corrections must be applied for steel separators and, likewise, for separators of fused quartz, which has a greater compressibility than that of steel.

Previous determinations of the compressibility of fused quartz proved disappointingly meager; consequently, this investigation was inaugurated with the hope that the compressibility of fused quartz might be determined with the accuracy of $5 \times 10^{-8}$ required for index of air measurements.

\section{METHODS FOR DETERMINING COMPRESSIBILITY}

Determination of the compressibility of fused-quartz glass was made by interferometric comparison of the relative change in length with pressure of end gages of fused quartz and stainless steel. Values for the compressibility of both fused quartz and stainless steel were determined by a direct method which depends upon the relative change in length of a closed tube and a solid gage of the same material. Relative values for fused quartz and steel were also derived from comparative changes in length with pressure of a tube of either of these materials and a gage of the other material.

\section{METHOD 1.-COMPARISON OF TWO GAGES OF UNLIKE MATERIALS}

Published values for compressibility of steel at pressures from 2,000 to 12,000 atmospheres give a straight line $(P-\Delta V)$ relationship. ${ }^{2}$ The accepted value for volume compressibility of soft steel is $6.0 \times 10^{-7}$ per megabar, which is equivalent to a longitudinal compressibility of $2.0 \times 10^{-7}$ per atmosphere. For fused quartz (fused silica glass) Adams, Williamson, and Johnston found an increasing compressibility for decreasing pressure. Their extrapolated value for atmospheric pressure is equivalent to a longitudinal compressibility of $10.1 \times 10^{-7}$ per atmosphere. The value for steel appears fairly well established, whereas that for fused quartz was considered somewhat questionable by its publishers.

By measuring the relative change in length with pressure of steel and fused quartz, and using the established value for steel, the com-

2 Adams, Williamson, and Johnston, J. Am. Chem. Soc. 41, 12-42 (1919). 
pressibility of fused quartz can be determined by sufficiently accurate measurements. For such determinations, two end gages of approximately equal length, one of fused quartz and the other of steel, were placed side by side in wringing contact with the plane surface of flat $B$, figure 1 . The relative change in length of the gages from atmospheric to vacuum pressure was determined by the shift of fringes resulting from interference of light waves between the upper surfaces of the gages and the lower surface of interferometer plate $T$, which was supported by the longer gage and inclined at a slight angle to give straight fringes of optimum measurable width.

Using the measured length differences for a pressure change of 1 atmosphere and the accepted value for the longitudinel compressi-

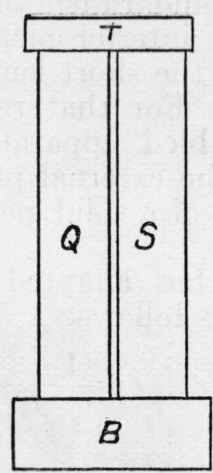

FRONT

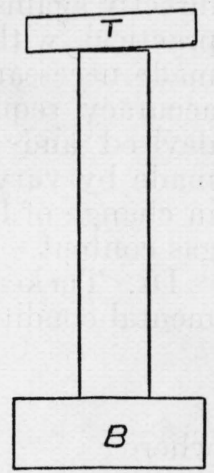

SIDE

FIgure 1.-Assembly of plates and gages for comparison of the compressibility of fused quartz and steel.

bility of steel, the longitudinal compressibility of fused quartz will be

where

$$
C_{Q}=\frac{\Delta L}{L}+C_{S}
$$

$C_{Q}=$ coefficient of longitudinal compressibility of fused quartz.

$C_{S}=$ coefficient of longitudinal compressibility of steel.

$\Delta L=$ measured relative change in length of the gages.

$L=$ length of the gages.

Preliminary tests indicated that the most precise control of temperature conditions was necessary to attain the desired accuracy. Measurements by this method gave values of sufficient merit to verify the reliability of the method next described.

\section{METHOD 2.-COMPARISON OF A CLOSED TUBE AND GAGE OF THE SAME MATERIAL}

The interesting fact that the compression modulus is the only elastic constant of an isotropic material which affects the longitudinal strain of a long, closed circular cylinder under a difierence of internal and external hydrostatic pressure was implicit in the equations given by Lamé ${ }^{3}$ as early as 1852 , but apparently Mallock ${ }^{4}$ was the first to realize the possibility of using it to measure the compression modulus. Dr. L. B. Tuckerman, of this Bureau, called attention to this work and suggested that a modification of Mallock's method could be used to determine the change of length of either fused quartz or steel with changing pressure, directly. This eliminates the existing uncertainty as to the value computed for the compressibility of steel at atmospheric pressure by extrapolation from much higher pressures, and eliminates, also, the uncertainty resulting from comparison of materials with different thermal expansivities.

\footnotetext{
${ }^{3}$ G. Lamé, Leşons sur la Théorie mathématique de l'Élasticité des Corps solides, 2d ed., p. 188-190, Gauthier-Villars, Paris (1866).

A. Mallock, On a direct method of measuring the coefficient of volume elasticity of metals. Proc. Roy. Soc. (London) 74, 50-52 (1904-05). See also footnote 5.
} 
Since Mallock used atmospheric pressure outside his tubes and varied the internal pressure, he could measure the change of length directly against a standard length at constant pressure. This was not practical with the interferometric method here used, which was made necessary by the short lengths of the gages and tubes and the accuracy required. For that reason, C. G. Peters, of this Bureau, devised and assembled apparatus with which measurements were made by varying the external pressure and measuring the difference in change of length of a solid gage and a sealed tube with a constant gas content.

Dr. Tuckerman has adapted Lamé's equations to these experimental conditions as follows:

where

$$
e=\frac{(1-2 \sigma)}{E} \frac{\left(\rho^{2} p_{i}-p_{0}\right)}{1-\rho^{2}}
$$

$p_{i}=$ change in internal pressure.

$p_{0}=$ change in external pressure.

$e=$ change in longitudinal strain.

$\rho=$ ratio of internal to external diameter.

$E=$ Young's modulus.

$\sigma=$ Poisson's ratio.

The quantity $(1-2 \sigma) / E$ is the longitudinal compressibility $C$, which, for isotropic materials, is $\frac{1}{3} k$, where $k$ is the modulus of cubic compressibility. If the material exhibits transversely symmetrical anisotropy, ${ }^{5} E$ and $\sigma$ are the elastic constants pertaining to purely axial stress. That formula 1 applies to this case as well as to the isotropic case has been verified by Dr. Tuckerman from an extension of Lamé's theory.

If a small hole is bored in the cylinder, $p_{i}=p_{0}$ at all times. This gives for an isotropic material $e=-C p_{0}=-C p_{i}$, as it should be for uniform hydrostatic pressure. If the cylinder is filled with a fluid with a modulus of cubic compressibility $k^{\prime}$ and sealed and then maintained at a constant temperature

$$
\begin{aligned}
& \quad \quad p_{i}=-\frac{k^{\prime} \Delta V}{V}=\frac{1}{1-\rho^{2}} \frac{k^{\prime}}{k}\left[\rho^{2} p_{i}-p_{0}+A\left(p_{i}-p_{0}\right)\right] \\
& A=\frac{2(1+\sigma)}{3(1-2 \sigma)} \\
& \sigma=\text { Poisson's ratio. } \\
& V=\text { volume of inclosed fluid. }
\end{aligned}
$$

Solving for $p_{i}$ gives

$$
\begin{aligned}
p_{i} & =\frac{\alpha}{1-(1-\alpha) \rho^{2}} p_{0} \\
\text { where } \alpha & =\frac{(1+A) \frac{k^{\prime}}{k}}{1+A \frac{k^{\prime}}{k}}
\end{aligned}
$$
5 A. E. H. Love, The Mathematical Theory of Elasticity, 4th ed., p. 160-161. (Cambridge Univ. Press,
1927.) 
Substituting for $p_{i}$ in eq 1 gives

$$
e=-C \frac{p_{0}}{1-(1-\alpha) \rho^{2}}
$$

Approximate values are

\begin{tabular}{|c|c|c|c|c|}
\hline & $k$ & $\sigma$ & A & $\alpha$ \\
\hline $\begin{array}{l}\text { Steel } \\
\text { Fused quartz }\end{array}$ & $\begin{array}{l}1.5 \times 10^{12} \\
3.5 \times 10^{11}\end{array}$ & $\begin{array}{l}0.3 \\
.15\end{array}$ & $\begin{array}{l}2 \\
1\end{array}$ & $\begin{array}{l}2 \times 10^{-6} \\
6 \times 10^{-6}\end{array}$ \\
\hline Gas at atmospheric pressure & $1.1 \times 10^{6}$ & & & \\
\hline
\end{tabular}

From eq $3^{\prime}$, $\alpha$ with a gas filling becomes so small as to be negligible and for all practical purposes

$$
e=-C \frac{p_{0}}{1-\rho^{2}}
$$

for $\rho^{2}=0.5$, which is the condition of equal areas of horizontal sections of the hole and of the material of the tube

$$
e=-2 C p_{0}
$$

For this special case, the change in length with pressure will be twice that of a solid bar of the same material.

For a transversely anisotropic material, the expression for $\alpha$, eq $3^{\prime}$, is different, but $\alpha$ is still negligible compared to 1 ; consequently, the result in eq 5 is the same.

These formulas are theoretically accurate only for a finite portion of an infinitely long cylinder. If, however, the end closure of the cylinder is made very rigid, the end effects can be neglected.

For making the measurements a fused-quartz tube was wrung to base plate $B$, figure 2 . Interferometer plate $T$ was wrung to the top of the tube, thereby closing it. A solid fused-quartz gage was wrung on $B$, beside the tube. A slight slope to the ends of the latter gave proper width to the fringes between $T$ and the gage. Measurements were made of the shifts of the fringes on the gage relative to a reference mark on $T$.

There was no noticeable distortion of the fringes during the shift.

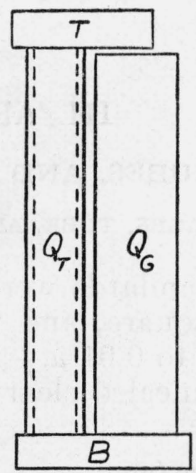

FRONT

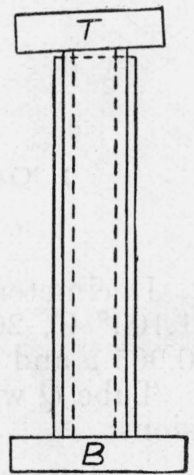

SIDE

Figure 2.-Assembly of fused-quartz tube and plates.

This showed that the end plates were sufficiently rigid and the end effects could safely be neglected. 
For a tube and gage of equal length, of identical material, and maintained at constant temperature, the coefficient of longitudinal compressibility for a change of external pressure of 1 atmosphere is

$$
C_{Q}=\frac{\Delta L}{L\left[\frac{1}{1-\rho^{2}}-1\right]}
$$

In a similar way the longitudinal compressibility of the steel gage and tube was determined.

\section{METHOD 3.-COMPARISON OF A TUBE AND GAGE OF UNLIKE MATERIALS}

For a closed tube the change in length with pressure is $1 /\left(1-\rho^{2}\right)$ times that of a solid gage, with no corresponding increase in uncertainties of measurements of length or temperature. Consequently, by comparing the change in length of a tube of a material with unknown compressibility and a gage of another material of known compressibility, the derived compressibility of the former should be more accurate than values determined by method 1 .

For a fused-quartz tube and a steel gage of equal length, maintained at constant temperature, the coefficient of longitudinal compressibility for a pressure change of 1 atmosphere will be

$$
C_{Q}=\frac{\Delta L+C_{s} L}{\left(\frac{1}{1-\rho^{2}}\right) L}
$$

By the use of a steel tube and a fused-quartz gage and, by using the value of $C_{a}$ found by method 3 , the longitudinal compressibility of steel will be

$$
C_{s}=\frac{C_{Q} L-\Delta L}{\left(\frac{1}{1-\rho^{2}}\right) L}
$$

\section{APPARATUS}

\section{GAGES, TUBES, AND INTERFEROMETER PLATES}

(a) END GAGES, TUBE, AND PLATES OF FUSED QUARTZ

Decimeter end standards were of clear fused quartz, annealed at $1,100^{\circ} \mathrm{C}, 20 \mathrm{~mm}$ square, and with end surfaces polished plane to $0.005 \mu$ and parallel to $0.01 \mu$.

Tube $Q$ was of annealed clear fused quartz of the following dimensions:

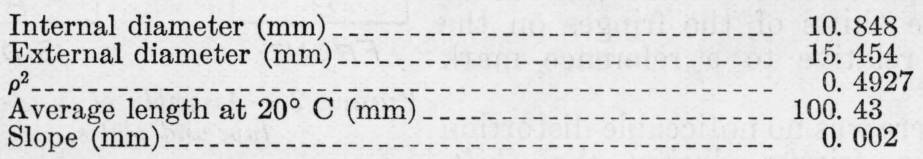

Its length was made slightly greater than $100 \mathrm{~mm}$ to permit wringing and substitution of gages beside it. The ends of the tube were polished plane, with no indications of rounding at the edges. 
End plates for the tube were of annealed fused quartz, optically polished plane to $0.01 \mu$ and of dimensions:

\begin{tabular}{|c|c|c|}
\hline Plate & $\begin{array}{c}\text { Diameter } \\
(\mathrm{mm})\end{array}$ & $\begin{array}{c}\text { Thickness } \\
(\mathrm{mm})\end{array}$ \\
\hline B & 46 & 10 \\
$T$ & 38 & 10 \\
\hline
\end{tabular}

(b) END GAGES AND TUBE OF STEEL; PLATES OF FUSED QUARTZ

In addition to two steel decimeter Johansson gage blocks, stainlesssteel end gages $20 \mathrm{~mm}$ square and $100.0000 \mathrm{~mm}$ long at $20^{\circ} \mathrm{C}$ were available. The following are known properties of this steel:

Analysis (\%) _._. $\mathrm{Cu} ; 0.07 \mathrm{Ni}$; and $13.9 \mathrm{Cr}$.

Heat treatment_...................... Heated to $950^{\circ} \mathrm{C}$, quenched in oil, and

Scleroscope hardness 55 . drawn at $600^{\circ} \mathrm{C}$.

Coefficient of thermal expansion.-- $10.2 \times 10^{-6}$.

End surfaces of the gages were fine-lapped plane and parallel to $0.02 \mu$. Faintly perceptible lap marks were partially removed by polishing lightly with rouge. A 1-mm hole, drilled perpendicularly from a side to the center of a gage, permitted insertion of a thermocouple junction.

A tube of identical material and with the same heat-treatment was made to dimensions:

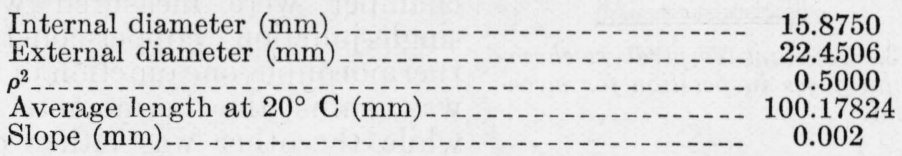

The planeness and polish of its end surfaces were less perfect than for the quartz-glass tube.

End plates for this tube were of annealed fused quartz, optically polished plane to $0.01 \mu$ and of dimensions:

\begin{tabular}{|c|c|c|}
\hline Plate & $\begin{array}{c}\text { Diameter } \\
(\mathrm{mm})\end{array}$ & $\begin{array}{c}\text { Thickness } \\
(\mathrm{mm})\end{array}$ \\
\hline & 57 & 21 \\
$B$ & 40 & 10 \\
\hline$T$ & & \\
\hline
\end{tabular}

\section{TEMPERATURE-CONTROL APPARATUS}

The temperature-control apparatus was that used by Souder and Peters. ${ }^{6}$ Their constant-temperature chamber, however, was replaced

\footnotetext{
- An investigation of the physical properties of dental materials. Dental Cosmos, p. 9 (March 1920).
} 
with a brass container $270 \mathrm{~mm}$ long, $67 \mathrm{~mm}$ in diameter, and of $1 \mathrm{~mm}$ thickness. Figure 3 shows this chamber with the gages in position for measurement. $W$ is a plane-parallel glass window sealed in place with wax. A survey of the stirred, ther-

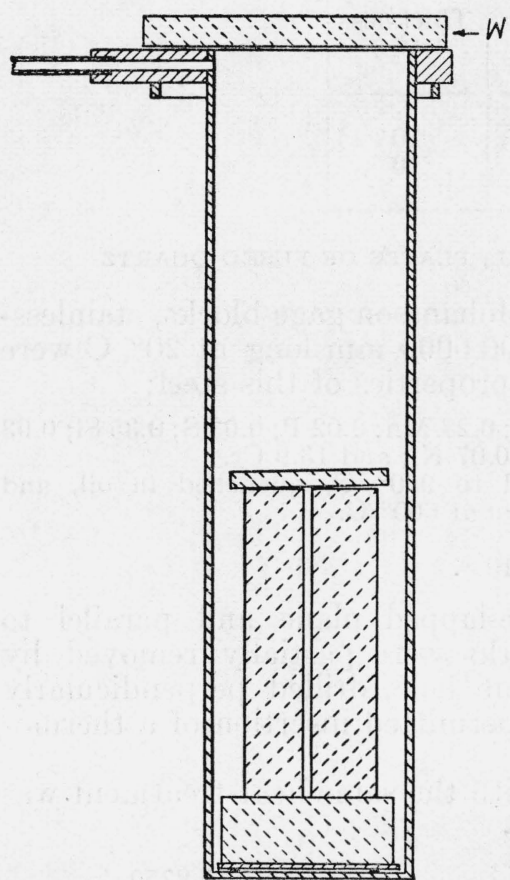

Figure 3.-Constant-temperature chamber, with gages in position for measurement. against the side of a quartz-glass gage or inserted to the center of a steel gage. Potential differences were measured by means of a potentiometer-galvanometer combination with a sensitivity of $2.4 \mathrm{~mm}$ per microvolt.

\section{AIR PUMP}

By the use of a rotary air pump, pressure within the chamber was held below $0.5 \mathrm{~mm}$, as indicated by a vacuum discharge tube.

\section{INTERFEROMETRIC MEASURING APPARATUS}

Relative changes and differences in length of tubes and gages were measured with a Pulfrich ${ }^{7}$ viewing instrument. A helium lamp incorporated within the Pulfrich served as a source of illumination and a direct-vision prism within the instrument separated the fringe patterns due to helium radiations of different wave lengths. For measurement of fringe shifts, the yellow radiation only was used; for measurement of length differences of tubes and gages, the following radiations were used:

\footnotetext{
7 Pulfrich, Z. Instrumentenk. 18, 261 (1898).
} 


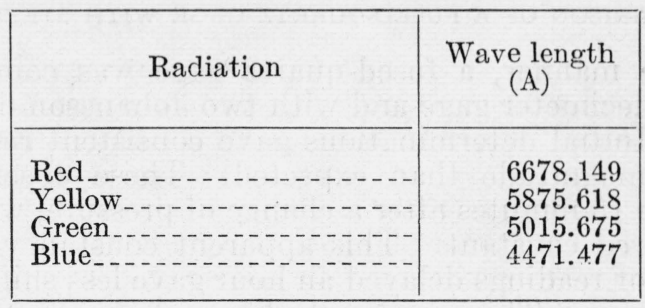

\section{EXPERIMENTAL PROCEDURE AND RESULTS}

\section{PRELIMINARY MEASUREMENTS}

\section{(a) COMPARISON OF TWO FUSED-QUARTZ GAGES}

Preliminary comparisons were made with fused-quartz decimeter end gages 3 and 6 wrung side by side on a fused-quartz flat. ${ }^{8}$ An interferometer plate of the same material formed a wedge with the top surfaces of the gages to give straight fringes of $2 \mathrm{~mm}$ width across the gage surfaces. The gages were placed within the chamber, controlled at $20^{\circ} \mathrm{C}$, which was then sealed and evacuated. After the fringes had become stationary, readings were taken by means of the Pulfrich of the position of a fringe on gage 6 relative to an opposite one on gage 3. Air was then admitted and the magnitude and direction of the fringe shift were noted. This procedure was repeated for fringes located at various places on the gages. Results gave no difference in compressibility greater than $3.5 \times 10^{-8}$ and gave a mean difference for the two quartz gages of zero. Table 1 summarizes the results of the determinations.

\section{TABLE 1.-Comparison of the compressibility of two fused-quartz gages}

\begin{tabular}{|c|c|c|c|c|}
\hline Reference fringe number & $\begin{array}{r}\text { Relative ch } \\
\text { of gage }\end{array}$ & $\begin{array}{l}\text { in length } \\
\text { and } 3\end{array}$ & $\begin{array}{c}\text { Equivalent } \\
\text { difference in } \\
\text { longitudinal }\end{array}$ & $\begin{array}{l}\text { Direction of } \\
\text { pressure change }\end{array}$ \\
\hline $\begin{array}{l}1 \\
2 \\
3 \\
4 \\
4\end{array}$ & $\begin{array}{l}\text { Fringe } \\
+0.012 \\
-.008 \\
+.008 \\
-.010 \\
-.002\end{array}$ & $\begin{array}{r}\mu \\
+0.0035 \\
-.0023 \\
+.0023 \\
-.0029 \\
-.0006\end{array}$ & $\begin{array}{l}+3.5 \times 10^{-8} \\
-2.3 \\
+2.3 \\
-2.9 \\
-0.6\end{array}$ & $\begin{array}{l}\text { Vacuum to air. } \\
\text { Vacuum to air. } \\
\text { Vacuum to air. } \\
\text { Air to vacuum. } \\
\text { Vacuum to air. }\end{array}$ \\
\hline
\end{tabular}

Mean difference in compressibility of gages 3 and $6=0.0 \times 10^{-8}$.

\footnotetext{
8 The method of wringing was, first, to clean the surfaces with alcohol and absorbent cotton. Next, the surfaces were covered with a thin film of grease by thoroughly rubbing with a cloth freshly impregnated with petroleum jelly. This film was reduced in thickness by vigorous rubbing and polishing with clean cotton until no trace of film was visible by reflected light. That edge of the gage to be measured was next brought gently into contact with the plate and the gage then allowed to grip in its desired position. Contact was indicated by a black appearance at the edge of the gage which gradually spread over its entire surface, provided the surfaces were thoroughly clean except for the minute film of grease. Rubbing had a tendency to attract small floating particles from the air to the surface. The presence of these was detected by the resulting colored or grayish appearance around the particles in the field of black contact. If particles were found to be present, the surfaces had to be separated and the process of wringing was then repeated until adherence was satisfactory. The separation is successfully effected by several hours immersion in water. It is believed, by this method of wringing surfaces of the perfection of those used, that the force of adherence was greater than $200 \mathrm{lb} / \mathrm{in}^{2}$. Experience over a period of years in the comparison of standard end gages indicates that the separation was less than $0.005 \mu$. Separations of this magnitude were found by other observers. (See F. H. Rolt, Gages and fine measurements 1, 164, 1929.)
} 
(b) COMPARISON OF A FUSED-QUARTZ GAGE WITH STEEL GAGES

In the same manner, a fused-quartz gage was compared with a stainless-steel decimeter gage and with two Johansson decimeter steel gage blocks. Initial determinations gave consistent results of somewhat greater magnitude than expected. These observations were made from 5 to 15 minutes after a change of pressure, when the fringe position appeared constant. This apparent constancy was misleading, however, for readings delayed an hour gave less shift for the same change of pressure. This was ascribed to a change in temperature of the gages.

(c) EFFECT OF CHANGE OF PRESSURE UPON TEMPERATURES WITHIN THE CHAMBER

Temperature measurements with differential thermocouples between the water bath and the center of the chamber and the center of the stainless-steel gage indicated that a change of pressure of 1 atmosphere caused measured changes of $25^{\circ} \mathrm{C}$ within the chamber. The change as measured was less than the actual initial effect owing to the lag of couple and galvanometer and to a rapid transfer of heat to the surroundings. Twenty minutes were required for the temperature of the air within the chamber and for the bath to attain an approximate equalization of $0.01^{\circ} \mathrm{C}$. In the meantime, the temperature of the steel gage was appreciably affected. After 9 minutes the temperature of the gage differed from that of the bath by $0.10^{\circ} \mathrm{C}$. The maximum difference was estimated to be $0.14^{\circ} \mathrm{C}$.

\section{(d) COOLING CURVES OF STEEL GAGES}

To investigate further the thermal relations between bath and gage under the conditions of measurement, cooling curves were taken for:

1. A steel gage wrung to a fused-quartz base plate (in air).

2. A steel gage wrung to a fused-quartz base plate (in vacuum).

3. A steel gage with a fused-quartz gage beside it (in air).

4. A steel gage with a fused-quartz gage beside it (in vacuum).

Rate of cooling was determined by temperature measurements with a thermocouple between the bath and the center of the steel gage at intervals from the time they were equal at an initial temperature until they were again equal after lowering the bath $1^{\circ} \mathrm{C}$. Variation in the time required to control the bath at the lower temperature confused early measurements; consequently, the curves (fig. 4) are given for a $0.75^{\circ} \mathrm{C}$ change, for which temperature difference thermal equilibrium had become established. Table 2 gives approximate values taken from the curves, supplemented by end values obtained during actual compressibility determinations. 


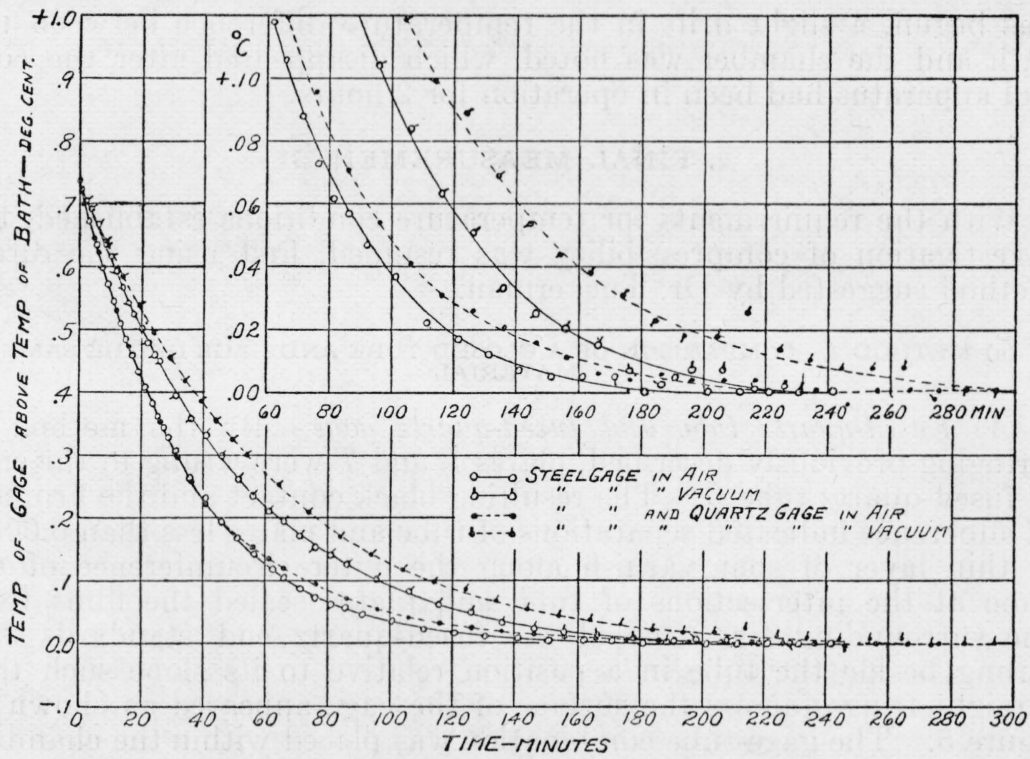

Figure 4.-Cooling curves of a steel gage.

TABLE 2.-Time required for cooling a steel gage

\begin{tabular}{|c|c|c|c|c|c|c|}
\hline \multirow{2}{*}{\multicolumn{3}{|c|}{$\begin{array}{l}\text { Difference in temperature of bath and } \\
\text { gage (temperature of bath greater } \\
\text { than temperature of gage) }\end{array}$}} & \multicolumn{4}{|c|}{ Approximate time required for change } \\
\hline & & & \multicolumn{2}{|c|}{ Steel gage alone in- } & \multicolumn{2}{|c|}{$\begin{array}{l}\text { Steel and quartz gages } \\
\text { side by side in- }\end{array}$} \\
\hline \multicolumn{2}{|c|}{ Difference } & \multirow{2}{*}{ Total change } & \multirow{2}{*}{ Air } & \multirow{2}{*}{ Vacuum } & \multirow{2}{*}{ Air } & \multirow{2}{*}{ Vacuum } \\
\hline Initial & Final & & & & & \\
\hline $\begin{array}{l}{ }^{\circ} \mathrm{C} \\
0.75 \\
.20 \\
.02\end{array}$ & $\begin{array}{l}{ }^{\circ} \mathrm{C} \\
0.20 \\
.02 \\
\pm .005\end{array}$ & $\begin{array}{l}.{ }^{\circ} \mathrm{C} \\
0.55 \\
.18 \\
.02 \pm 0.005\end{array}$ & $\begin{array}{r}\min \\
45 \\
70 \\
65\end{array}$ & $\begin{array}{r}\min \\
65 \\
90 \\
70\end{array}$ & $\begin{array}{r}\min \\
45 \\
90 \\
75\end{array}$ & $\begin{array}{r}\min \\
75 \\
115 \\
75\end{array}$ \\
\hline \multicolumn{3}{|c|}{$\begin{array}{l}\text { Total time to change from } \Delta=0.75^{\circ} \text { to } \\
\Delta= \pm 0.005^{\circ} \\
\text { Total time to change from } \Delta=0.20^{\circ} \text { to } \\
\Delta= \pm 0.005^{\circ}\end{array}$} & $\begin{array}{l}180 \\
135\end{array}$ & $\begin{array}{l}225 \\
160\end{array}$ & $\begin{array}{l}210 \\
165\end{array}$ & $\begin{array}{l}265 \\
190\end{array}$ \\
\hline
\end{tabular}

For the conditions of the compressibility experiments in which the change in temperature of the gage was $0.14^{\circ} \mathrm{C}$, measurements for the steel-fused quartz combination should be delayed at least $2 \frac{1}{2}$ hours for air and 3 hours for vacuum after a change of pressure.

(e) TIME REQUIRED TO ESTABLISH THERMAL EQUILIBRIUM WITHIN THE CONSTANT-TEMPERATURE CHAMBER

Another effect investigated was the time required to establish thermal equilibrium within the constant-temperature chamber itself. In practice, the desired temperature was often 2 or $3^{\circ}$ different from the overnight temperature of the apparatus. After control 
was begun, a slight drift in the temperature difference between the bath and the chamber was noted, which disappeared after the control apparatus had been in operation for 2 hours.

\section{FINAL MEASUREMENTS}

With the requirements for temperature conditions established, the investigation of compressibility was resumed, first using the direct method suggested by Dr. Tuckerman.

(a) METHOD 2.-COMPARISON OF A CLOSED TUBE AND GAGE OF THE SAME MATERIAL

(1) Fused-quartz tube and fused-quartz gage.-By the method of wringing previously described, plates $B$ and $T$ were wrung to the ends of fused-quartz tube $Q$. The resulting black contact and the firmness of adherence indicated separations of tube and plates less than $0.005 \mu$. A thin layer of spar varnish along the outer circumference of the tube at the intersections of tube and plates sealed the films from the surrounding air. One of the fused-quartz end standards was wrung beside the tube in a position relative to its slope such that straight fringes across the surface of the gage appeared as shown in figure 5. The gage-tube combination was placed within the chamber,

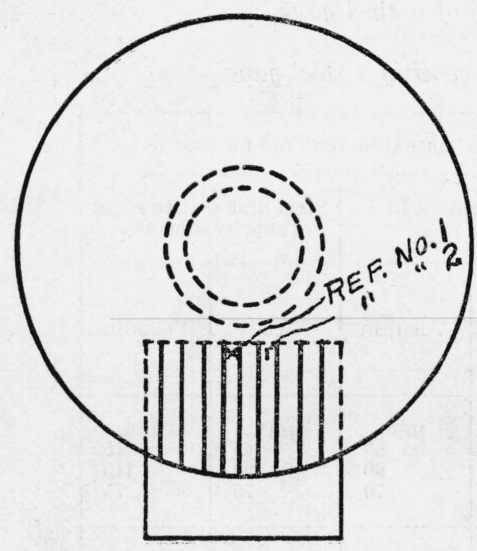

Frgure 5-Appearance of the fringes and position of reference marks for the gage-tube combination. which was controlled at the temperature found in the morning. Window $W$ was sealed to the top of the chamber. A stopcock in the line to the pump was opened to the room.

After temperature equilibrium had become established, in all cases at least 2 hours later, the position of a definite fringe of helium yellow was measured relative to a reference mark on plate $T$, by means of the Pulfrich. Usually 8 to 10 individual measurements were made for each position of a fringe. The maximum variation from the mean was 0.005 fringe. (This exactness of setting was due to the high degree of planeness of surfaces and to the tendency of an observer to establish a definite, repeatable criterion for the center of gravity of a fringe.) Barometric pressure and bath temperature were recorded.

Upon completion of these measurements, the stopcock was closed to the air; the pump was started and continued in operation until all measurements in vacuo were completed. The direction of fringe shift was noted. The vacuum discharge tube indicated a pressure less than $0.5 \mathrm{~mm}$. Since the materials in this case were identical and of low thermal expansivity, little time was required to reach a stable condition. Readings made 30 to 210 minutes after a change of pressure gave no differences ascribable to temperature. In several instances, air was again admitted to the chamber and remeasurement of the fringe position was made. 
Measurement of the distance between plate $T$ and the upper surface of the gage by using the red, yellow, green, and blue radiations of helium gave a separation of $0.434 \mathrm{~mm}$.

Three series of measurements were made for pressure changes from air to vacuum and from vacuum to air. Later, the gage was rewrung to the plate, and two additional series were made for pressure changes from air to vacuum. Measurements of two individual fringes differed from the mean by 0.003 fringe.

Pressure differences for these tests varied from 742 to $761 \mathrm{~mm}$; gage temperatures varied from 20 to $24^{\circ} \mathrm{C}$.

The measured fringe shifts varied from 0.065 to 0.077 fringe. These, however, were not the true fringe shifts caused by compressibility; a correction was necessary for the shift due to the change of wave length with air density. For a $0.434-\mathrm{mm}$ gap, this shift was six times the measured shift and in a direction opposite to that attributable to compressibility. Since the indices of air are known to a higher order of accuracy than was here required, corrections were applied with confidence to the measured fringe shift. From the true fringe shift, corrected to a pressure change of 1 atmosphere, and from the dimensions of gage and tube, the coefficient of longitudinal compressibility, $\mathrm{C}_{\theta}$, was determined.

$$
\text { True shift }=\Delta_{Q}=\left(\frac{p_{0}}{1-\rho^{2}}\right) C_{Q} L_{T}-p_{0} L_{G} C_{Q}
$$

For $p_{0}=1$ atmosphere, and $\rho^{2}=0.4927$

$$
C_{Q}=\frac{\Delta}{1.9713 L_{T}-L_{G}}
$$

where $\Delta=$ true shift for a pressure change of 1 atmosphere.

Table 3 gives a summary of the measurements of the compressibility of quartz by this method. Extreme values were $\mathrm{C}_{Q}=9.7 \times 10^{-7}$ to $\mathrm{C}_{Q}=10.1^{-7}$ with a mean value $\mathrm{C}_{Q}=9.9 \times 10^{-7}$ per atmosphere. 
TABLE 3.-Compressibility determinations using a tube and gage of the same material

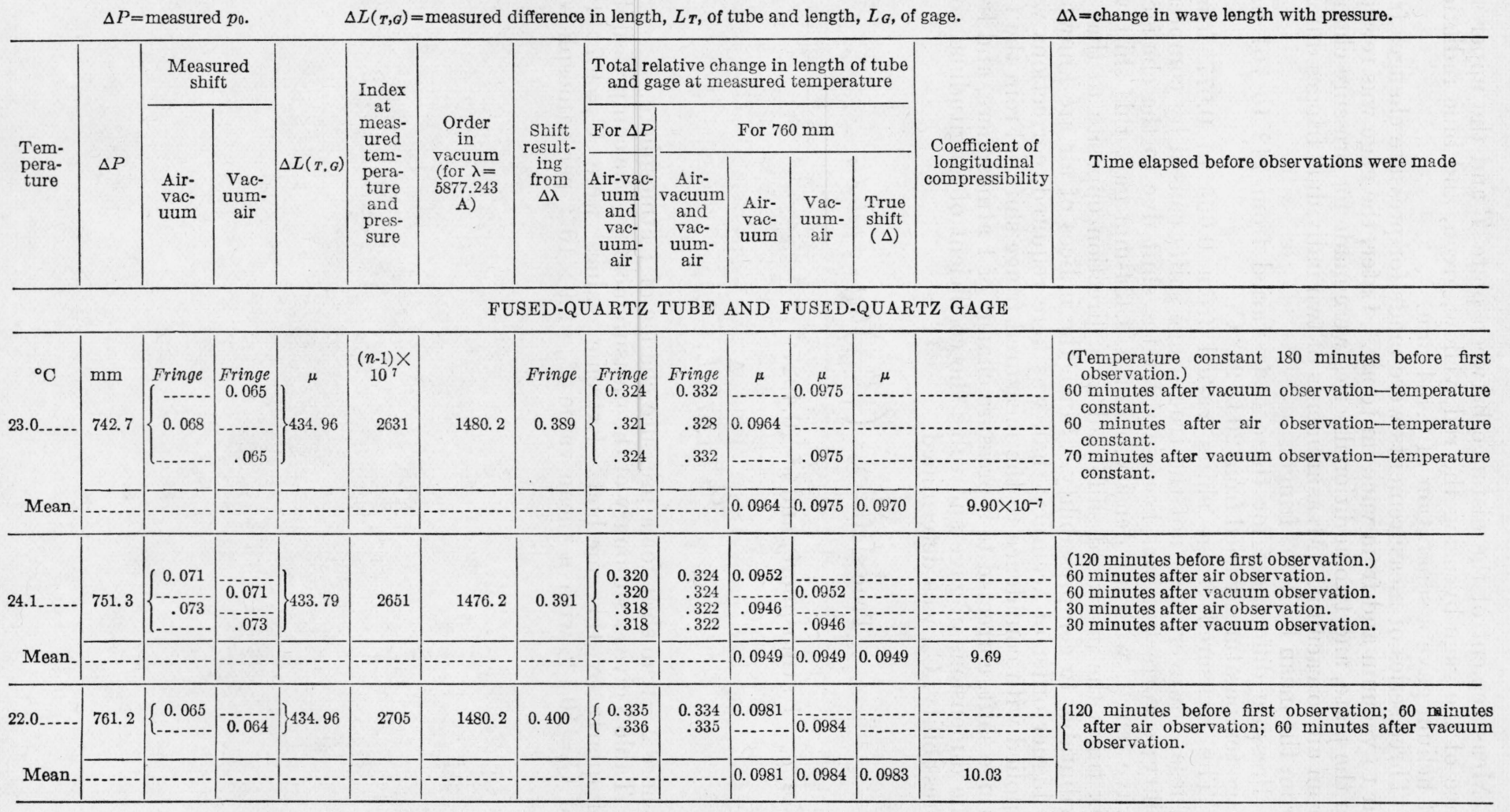


Rewrung Quartz Gage

\begin{tabular}{|c|c|c|c|c|c|c|c|c|c|c|c|c|c|c|}
\hline $20.0 \ldots$ & 743.0 & $\left\{\begin{array}{r}a 0.067 \\
b .064\end{array}\right.$ & $\mid-\ldots$. & $\begin{array}{l}435.0- \\
435.0+\end{array}$ & 2659 & 1480.2 & 0.394 & $\left\{\begin{array}{r}0.327 \\
.330\end{array}\right.$ & $\begin{array}{r}0.334 \\
.338\end{array}$ & $\begin{array}{r}0.0981 \\
.0993\end{array}$ & $\mid-\ldots-1$. & $\cdots$ & 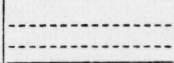 & \multirow[t]{2}{*}{$\begin{array}{c}210 \text { minutes before first observation; } 210 \text { minutes } \\
\text { after air observation. }\end{array}$} \\
\hline Mean. & -..- & 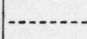 & & & $\cdots$ & - & -...- & -........ & -........ & 0.0987 & & 0.0987 & 10.07 & \\
\hline $20.0 \ldots$ & 751.9 & $\left\{\begin{array}{r}a 0.077 \\
b .072\end{array}\right.$ & & $\begin{array}{l}435.0- \\
435.0+\end{array}$ & 2691 & 1480.2 & 0.398 & $\left\{\begin{array}{r}0.321 \\
.326\end{array}\right.$ & $\begin{array}{r}0.324 \\
.330\end{array}$ & $\begin{array}{r}0.0952 \\
.0970\end{array}$ & & - & & \multirow[t]{3}{*}{$\begin{array}{l}130 \text { minutes before first observation; } 80 \text { minutes } \\
\text { after air observation. }\end{array}$} \\
\hline Mean. & -....... & 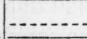 & $\ldots$ & $-\ldots \ldots$ & - & - & -....... & 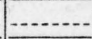 & 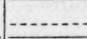 & 0.0961 & -....... & 0.0961 & 9.81 & \\
\hline Mean. & $\ldots \ldots$ & $\ldots$ & & $\ldots$ & & -......... & -........ & & $\ldots$ & & 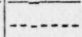 & $\ldots$ & $C_{Q}=9.9 \times 10^{-7}$ & \\
\hline
\end{tabular}

STEEL TUBE AND STEEL GAGE

\begin{tabular}{|c|c|c|c|c|c|c|c|c|c|c|c|c|c|c|}
\hline $23.55 \ldots$ & 758.2 & $\left\{\begin{array}{c}0.053 \\
\cdots \\
0.054\end{array}\right.$ & $\begin{array}{c}0.063 \\
-.052 \\
-0 .-1-1\end{array}$ & 178.21 & 2681 & 605.4 & 0.163 & $\left\{\begin{array}{l}0.100 \\
.110 \\
.111 \\
.109\end{array}\right.$ & $\begin{array}{l}0.100 \\
.110 \\
.111 \\
.109\end{array}$ & $\begin{array}{l}0.0323 \\
0.0320\end{array}$ & 0.0294 & & 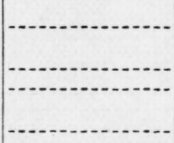 & $\begin{array}{l}70 \text { minutes after vacuum observation-until } \Delta_{T} \text { is } \\
\text { constant. } \\
67 \text { minutes after air observation-until } \Delta_{T} \text { is constant. } \\
53 \text { minutes after vacuum observation - until } \Delta_{T} \text { is } \\
\text { constant. } \\
35 \text { minutes after air observation-until } \Delta_{T} \text { is constant. }\end{array}$ \\
\hline Mean. & - & - & .......... & - & - & - & - & - & ......... & -0.0322 & 0.0310 & 0. 0316 & $3.15 \times 10^{-7}$ & \\
\hline $22.6 \ldots$ & 761.5 & $\left\{\begin{array}{c}0.049 \\
0.047 \\
.04\end{array}\right.$ & $\begin{array}{l}0.064 \\
-.057 \\
-.052\end{array}$ & 178.21 & 2701 & 606.4 & .164 & $\left\{\begin{array}{l}0.100 \\
.115 \\
.107 \\
.117 \\
.112\end{array}\right.$ & $\begin{array}{l}0.100 \\
.115 \\
.107 \\
.117 \\
.112\end{array}$ & \begin{tabular}{l}
0.0338 \\
\hdashline .0344 \\
\hdashline$-1 .-1$
\end{tabular} & $\begin{array}{c}0.0294 \\
-.0314 \\
-.0329\end{array}$ & & & $\begin{array}{l}70 \text { minutes after vacuum observation-until } \Delta_{T} \text { is } \\
\text { constant. } \\
70 \text { minutes after air observation-until } \Delta T \text { is constant. } \\
60 \text { minutes after vacuum observation-until } \Delta_{T} \text { is } \\
\text { constant. } \\
65 \text { minutes after air observation-until } \Delta T \text { is constant. } \\
70 \text { minutes after vacuum observation - until } \Delta_{T} \text { is } \\
\text { constant. }\end{array}$ \\
\hline Mean_ & & ...... & & & & & & & - & 0.0341 & 0.0312 & 0.0327 & 3.26 & \\
\hline
\end{tabular}


TABLE 3.-Compressibility determinations using a tube and gage of the same material-Continued

\begin{tabular}{|c|c|c|c|c|c|c|c|}
\hline \multirow[b]{2}{*}{$\begin{array}{l}\text { Tem- } \\
\text { pera- } \\
\text { ture }\end{array}$} & \multirow[b]{2}{*}{$\Delta P$} & \multicolumn{2}{|c|}{$\begin{array}{c}\text { Measured } \\
\text { shift }\end{array}$} & \multirow[b]{2}{*}{$\Delta L(T, \theta)$} & \multirow{2}{*}{$\begin{array}{c}\text { Index } \\
\text { at } \\
\text { meas- } \\
\text { ured } \\
\text { tem- } \\
\text { pera- } \\
\text { ture } \\
\text { and } \\
\text { pres- } \\
\text { sure }\end{array}$} & \multirow[b]{2}{*}{$\begin{array}{c}\text { Order } \\
\text { in } \\
\text { vacuum } \\
\text { (for } \lambda= \\
5877.243 \\
\text { A) }\end{array}$} & \multirow[b]{2}{*}{$\begin{array}{c}\text { Shift } \\
\text { result- } \\
\text { ing } \\
\text { from } \\
\Delta \lambda\end{array}$} \\
\hline & & $\begin{array}{l}\text { Air- } \\
\text { vac- } \\
\text { uum }\end{array}$ & $\begin{array}{l}\text { Vac- } \\
\text { uum- } \\
\text { air }\end{array}$ & & & & \\
\hline
\end{tabular}

\begin{tabular}{|c|c|c|c|c|c|}
\hline \multicolumn{5}{|c|}{$\begin{array}{l}\text { Total relative change in length of tube } \\
\text { and gage at measured temperature }\end{array}$} & \multirow{3}{*}{$\begin{array}{l}\text { Coefficient of } \\
\text { longitudinal } \\
\text { compressibility }\end{array}$} \\
\hline For $\Delta P$ & \multicolumn{4}{|c|}{ For $760 \mathrm{~mm}$} & \\
\hline $\begin{array}{l}\text { Air-vac- } \\
\text { uum } \\
\text { and } \\
\text { vac- } \\
\text { uum- } \\
\text { air }\end{array}$ & $\begin{array}{c}\text { Air- } \\
\text { vacuum } \\
\text { and } \\
\text { vac- } \\
\text { uum- } \\
\text { air }\end{array}$ & $\begin{array}{l}\text { Air- } \\
\text { vac- } \\
\text { uum }\end{array}$ & $\begin{array}{l}\text { Vac- } \\
\text { uum- } \\
\text { air }\end{array}$ & $\begin{array}{l}\text { True } \\
\text { shift } \\
(\Delta)\end{array}$ & \\
\hline
\end{tabular}

Time elapsed before observations were made

Rewrung Steel Gage

\begin{tabular}{|c|c|c|c|c|c|c|c|c|c|c|c|c|c|c|}
\hline${ }^{\circ} \mathrm{C}$ & $\begin{array}{c}\mathrm{mm} \\
747.5\end{array}$ & $\begin{array}{r}\text { Fringe } \\
\left\{\begin{array}{r}0.073 \\
d .071\end{array}\right.\end{array}$ & Fringe & $\begin{array}{c}\mu \\
178.24\end{array}$ & $\mid \begin{array}{c}(n=1) \times \\
10^{7} \\
2675\end{array}$ & 606.5 & $\begin{array}{r}\text { Fringe } \\
0.162\end{array}$ & $\left\{\begin{array}{r}\text { Fringe } \\
0.089 \\
.091\end{array}\right.$ & $\begin{array}{r}\text { Fringe } \\
0.091 \\
.093\end{array}$ & $\begin{array}{c}\mu \\
0.0267 \\
.0273\end{array}$ & $\begin{aligned} \mu \\
--\cdot\end{aligned}$ & $\begin{array}{c}\mu \\
-\cdots\end{array}$ & & \multirow[t]{2}{*}{$\begin{array}{c}\Delta T \text { constant } 130 \text { minutes before first observation; } \Delta T \\
\text { constant } 130 \text { minutes after air observation. }\end{array}$} \\
\hline Mean_ & -...- & - & -....... & - & $-\ldots-$ & - & -....... & - & - & 0.0270 & - & 0.0270 & 2.69 & \\
\hline $19.4 \ldots \ldots$ & 747.2 & $\left\{\begin{array}{r}c 0.050 \\
d .054\end{array}\right.$ & - & $\{178.24$ & 2679 & 606.5 & 0.163 & $\left\{\begin{array}{r}0.113 \\
.109\end{array}\right.$ & $\begin{array}{r}0.115 \\
.111\end{array}$ & $\begin{array}{r}0.0338 \\
.0326\end{array}$ & & $-\cdots$ & (n) & \multirow[t]{3}{*}{$\begin{array}{c}\Delta T \text { constant } 180 \text { minutes before first observation; } \Delta_{T} \\
\text { constant } 160 \text { minutes after air observation. }\end{array}$} \\
\hline Mean. & $\ldots$ & -........ & -...... & - & - & - & -....... & $-\ldots-\ldots$ & - & 0.0332 & $\ldots$ & 0.0332 & 3.31 & \\
\hline Mean. & & & & & & & & & & & & -....... & $C_{S}=3.1 \times 10^{-i}$ & \\
\hline
\end{tabular}

$a=$ measured shift of first fringe.

$b=$ measured shift of second fringe.

$c=$ measured shift from first reference mark.

$d=$ measured shift from second reference mark. 
(2) Steel tube and steel gage.-Plates $B$ and $T$ were wrung to the ends of the steel tube previously described. In this case the black contact did not extend to the outer circumference of the tube. This was attributed to a lack of sufficient planeness and polish of the ends of the tube. A slight "rounding off" at its edges was observed. In sealing the separations between surfaces, the spar varnish had a tendency to creep between the tube and the plates. The effect of this will be discussed later. Steel end gage 2 was wrung beside the tube on plate $B$.

One junction of a copper-constantan thermocouple was inserted in the hole of the gage in contact with the metal at its center; the other junction was in contact with the bulb of the bath thermometer.

Two series of observations were made with an initial wringing of gage 2 for air-vacuum and vacuum-air pressure changes after thermocouple measurements indicated that bath and gage temperatures were constant. The fringe shifts from vacuum to air were greater than those from air to vacuum by 0.004 and 0.010 fringe, respectively, for the two series. Since the temperature of the tube and of the gage may not have become equalized during the short intervals of 35 to 70 minutes between change-overs, the mean value for the two conditions was used. Later, with a rewringing of gage 2, two series of observations were made for air-vacuum pressure changes with delays of 130 and 160 minutes between readings. Fringe shifts were measured relative to two reference marks.

The measured separation of gage and plate was $0.1782 \mathrm{~mm}$. For this separation, the correction attributable to the change of wave length with air density was three times the measured shift and opposite in direction to the compressibility shift.

For this steel tube-gage combination, the coefficient of longitudinal compressibility for $p_{0}=1$ atmosphere and $\rho^{2}=0.5$ was

$$
C_{S}=\frac{\Delta}{2 L_{T}-L_{G}}
$$

Measurements and results for these determinations are given in table 3. The value $C_{S}=2.7 \times 10^{-7}$ appears somewhat at variance with those of other series. At the time of measurement, series 3 and 4 were considered equally good; consequently, it must be included, thus giving a maximum spread from the mean value of $0.4 \times 10^{-7}$.

The mean of all series was

$$
C_{S}=3.1 \times 10^{-7} \text { per atmosphere }
$$

(b) METHOD 3.-COMPARISON OF A TUBE AND GAGE OF UNLIKE MATERIALS

(1) Fused-quartz tube and steel gage.-Steel gage 2 was next wrung beside the fused-quartz tube. Two series of comparative compressibility determinations were made; the first included vacuum-air and air-vacuum changes; the second was for vacuum-air only. In each series sufficient time was allowed before and after the changeover for thermal conditions to become constant. 
The coefficient of longitudinal compressibility of quartz glass was derived from the equation

$$
C_{Q}=\frac{\Delta+L_{G} C_{S}}{1.9713 L_{T}}
$$

Measurements and results are given in table 4 . Using value $C_{S}=3.1 \times$ $10^{-7}$ found by method 2 , values for $C_{Q}$ were $10.2 \times 10^{-7}$ and $10.0 \times 10^{-7}$ for the two series or a mean value

$$
C_{Q}=10.1 \times 10^{-7} \text { per atmosphere }
$$

By substitution of $C_{Q}=9.9 \times 10^{-7}$ as found by method 2, in the equation

$$
C_{S}=\frac{1.9713 L_{T} C_{Q}-\Delta}{L_{G}}
$$

the mean value of the coefficient of steel required by these measurements was

$$
C_{S}=2.7 \times 10^{-7} \text { per atmosphere }
$$

It must be appreciated that this latter substitution is not particularly desirable. The change in length of the tube with pressure is twice that of a solid gage, whereas the uncertainties attributable to temperature and fringe measurements remain the same for tube and gage. Furthermore, any error in the coefficient of compressibility of the tube results in double that error for the determined coefficient of the gage. 
TABLE 4.-Compressibility determinations using a tube and gage of unlike materials

\begin{tabular}{|c|c|c|c|c|c|c|c|c|c|c|c|c|c|c|c|}
\hline \multirow{3}{*}{$\begin{array}{l}\text { Tem- } \\
\text { pera- } \\
\text { ture }\end{array}$} & \multirow{3}{*}{$\Delta P$} & \multicolumn{2}{|c|}{$\begin{array}{l}\text { Measured } \\
\text { shift }\end{array}$} & \multirow{3}{*}{$\Delta L_{T G}$} & \multirow{3}{*}{$\begin{array}{c}\text { Index } \\
\text { at } \\
\text { measured } \\
\text { tempera- } \\
\text { ture and } \\
\text { pressure }\end{array}$} & \multirow{3}{*}{$\begin{array}{c}\text { Order } \\
\text { in } \\
\text { vacuum } \\
\text { (for } \lambda= \\
5877.243 \mathrm{~A})\end{array}$} & \multirow{3}{*}{$\begin{array}{c}\text { Shift } \\
\text { result- } \\
\text { ing } \\
\text { from } \\
\Delta \lambda \\
\end{array}$} & \multicolumn{5}{|c|}{$\begin{array}{l}\text { Total relative change in length of tube } \\
\text { and gage at measured temperature }\end{array}$} & \multicolumn{2}{|c|}{$\begin{array}{l}\text { Coefficient of longitudinal } \\
\text { compressibility }\end{array}$} & \multirow{3}{*}{$\begin{array}{c}\text { Time elapsed before } \\
\text { observations were } \\
\text { made }\end{array}$} \\
\hline & & & & & & & & \multirow{2}{*}{$\begin{array}{c}\text { For } \Delta P \\
\text { Air- } \\
\text { vacuum } \\
\text { and } \\
\text { vac- } \\
\text { uum- } \\
\text { air }\end{array}$} & \multicolumn{4}{|c|}{ For $760 \mathrm{~mm}$} & \multirow[b]{2}{*}{ Tube vs. gage } & \multirow{2}{*}{$\begin{array}{l}\text { Gage vs. tube } \\
\text { (Note: errors } \\
\text { > by this } \\
\text { method) }\end{array}$} & \\
\hline & & $\begin{array}{l}\text { vac- } \\
\text { uum }\end{array}$ & air & & & & & & $\begin{array}{l}\text { vacuum } \\
\text { and } \\
\text { vac- } \\
\text { uum- } \\
\text { air }\end{array}$ & $\begin{array}{c}\text { Air } \\
\text { vac- } \\
\text { uum- }\end{array}$ & $\begin{array}{l}\text { Vac- } \\
\text { uum- } \\
\text { air }\end{array}$ & $\begin{array}{l}\text { True } \\
\text { shift } \\
(\Delta)\end{array}$ & & & \\
\hline \multicolumn{16}{|c|}{ FUSED-QUARTZ TUBE AND STEEL GAGE } \\
\hline${ }^{\circ} \mathrm{C}$ & $\mathrm{mm}$ & Fringe & Fringe & $\mu$ & $(n-1) \times 10^{7} \mid$ & & Fringe & Fringe & Fringe & $\mu$ & $\mu$ & $\mu$ & $\mid\left(\right.$ Use $\left.C_{S}=3.1 \times 10^{-7}\right) \mid$ & (Use $\left.C_{Q}=9.9 \times 10^{-7}\right)$ & 130 minutes before first vac- \\
\hline 22.9 & 760.7 & $\{0.183\}$ & 0.186 & \} 431.79 & 2695 & 1469.4 & 0.396 & $\left\{\begin{array}{r}0.582 \\
.579\end{array}\right\}$ & $\begin{array}{r}0.581 \\
.578\end{array}$ & 0.1701 & 0.1707 & \} 0.1704 & $10.17 \times 10^{-7}$ & $2.56 \times 10^{-7}$ & $\left\{\begin{array}{l}\text { uum observation; } 190 \text { min- } \\
\text { utes before air observation; } \\
120 \text { minutes before second } \\
\text { vacuum observation. }\end{array}\right.$ \\
\hline 23.0 & 760.3 & $-\ldots . . .+$ & .174 & 431.69 & 2693 & 1469.0 & .396 & .570 & .570 & $\mid-\cdots+\cdots$ & .1675 & .1675 & 10.03 & 2.85 & $\left\{\begin{array}{c}230 \text { minutes before vacuum } \\
\text { observation; } 190 \text { minutes } \\
\text { before air observation. }\end{array}\right.$ \\
\hline Mean. & $-\cdots+$ & $\mid \cdots \cdots$ & $-\cdots-\cdots$ & $-\cdots+\cdots$ & $\mid \ldots \ldots \ldots$ & $\mid \ldots \ldots \ldots$ & 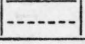 & -.......... & $-\cdots$ & $+\cdots$ & $\mid-\cdots$ & $-\ldots \ldots$ & $C_{Q}=10.1 \times 10^{-7}$ & $C_{S}=2.7 \times 10^{-7}$ & \\
\hline \multicolumn{16}{|c|}{ STEEL TUBE AND FUSED-QUARTZ GAGE } \\
\hline 25.0 & 754.1 & $\left\{\begin{array}{l}0.285 \\
-\cdots\end{array} \mid\right.$ & 0.333 & 182.43 & 2653 & 620.8 & 0.165 & $\left\{\begin{array}{r}0.120 \\
.168\end{array}\right.$ & $\begin{array}{r}0.121 \\
.169\end{array}$ & 0.0355 & 0.0496 & 0.0426 & $\mid \begin{array}{r}\left(\text { Use } C_{Q}=9.9 \times 10^{-7}\right) \\
2.82 \times 10^{-7}\end{array}$ & $\left|\begin{array}{r}\left(\text { Use } C_{S}=3.1 \times 10^{-7}\right) \\
10.47 \times 10^{-7}\end{array}\right|$ & $\begin{array}{l}\left\{\begin{array}{c}160 \text { minutes before first air } \\
\text { observation; } 170 \text { minutes } \\
\text { before vacuum observa- } \\
\text { tion; } 110 \text { minutes before } \\
\text { second sir observation. }\end{array}\right. \\
150 \text { minutes before first air }\end{array}$ \\
\hline 23.0 & 751.3 & $\left\{\begin{array}{c}.250 \\
\cdots\end{array} \mid\right.$ &. .318 & \} 180.49 & 2661 & 614.2 & .163 & $\left\{\begin{array}{l}.087 \\
.155\end{array}\right.$ & .088 & .0259 & .0461 & .0360 & 3.14 & 9.81 & $\left\{\begin{array}{l}150 \text { minutes before first air } \\
\text { observation; } 170 \text { minutes } \\
\text { before vacuum observa- } \\
\text { tion; } 130 \text { minutes before } \\
\text { second air observation. }\end{array}\right.$ \\
\hline 23.5 & 744.0 & .280 & $-\ldots$ & 180.98 & 2631 & 615.9 & .162 & .118 & .121 & .0355 & $\ldots$ & .035 & 3.17 & 9. 76 & $\left\{\begin{array}{l}240 \text { minutes before air obser- } \\
\text { vation; } 180 \text { minutes before } \\
\text { vacuum observation. }\end{array}\right.$ \\
\hline Mean. & -...... & $\mid \cdots$ & $\ldots$ & -....... & $\mid$ & $\mid \ldots \ldots$ & $\mid \ldots \ldots$ & $\mid$ & $\ldots$ & $\ldots$ & -.......... & $|\ldots \ldots|$ & $C_{S}=3.0 \times 10^{-7}$ & $C_{Q}=10.0 \times 10^{-7}$ & \\
\hline
\end{tabular}


(2) Steel tube and fused-quartz gage.-Three series of measurements were made with a fused-quartz gage wrung beside the steel tube. Observations were made in two series for vacuum-air and air-vacuum pressure changes. Fringe shifts for the two conditions differed by 0.048 and 0.068 fringe, respectively. In view of the fact that no difference for these two conditions had been observed previously, it was believed that sufficient time had not elapsed before measurements were made. Temperature measurements were made at the surface of the gage. Since the elapsed time was about the same for the two conditions, their mean value would approximate the true value. In the third series, for which an air-vacuum change only was made, the calorimeter was regulated 240 minutes before initial readings were taken; 180 minutes elapsed after the pressure change before final measurements were made. The result differed from the mean of the first two series by 0.013 fringe.

By substitution of $C_{0}=9.9 \times 10^{-7}$ (the value determined by method 2 ), values for the coefficient of longitudinal compressibility for steel were derived from:

$$
C_{s}=\frac{L_{a} C_{Q}-\Delta}{2 L_{T}}
$$

Measurements and results are given in table 4. The derived values varied from $2.8 \times 10^{-7}$ to $3.2 \times 10^{-7}$ with a mean value

$$
C_{s}=3.0 \times 10^{-7} \text { per atmosphere }
$$

By the less accurate method of derivation of the compressibility of the gage from an assumed compressibility of the tube, and by substituting $C_{s}=3.1 \times 10^{-7}$ in the equation:

$$
C_{a}=\frac{\Delta+2 L_{r} C_{s}}{L_{a}}
$$

the derived mean value of $\mathrm{C}_{Q}$ was

$$
C_{Q}=10.0 \times 10^{-7} \text { per atmosphere }
$$

(c) METHOD 1.-COMPARISON OF TWO GAGES OF UNLIKE MATERIALS

To verify the relative results for fused quartz and steel which were determined by the closed-tube methods, final comparative determinations were made with gages of fused quartz and steel wrung, side by side, on a fused-quartz plate.

Black contact resulted from the wringing of the fused-quartz standard with a correspondingly great adherence. The adherence of the steel gage with its lapped and slightly polished surface was appreciably less. One junction of the thermocouple was in contact with the metal at the center of the steel gage; the other junction was in contact with the bulb of the bath thermometer. The wedge between the surfaces of the gages and the interferometer plate was produced by a cotton fiber as a separator. It was found, however, that change of pressure caused a slight tilting of the plate which affected the fringe position. To overcome this difficulty, two pieces of gold leaf $1.5 \mathrm{~mm}$ square were placed in adjacent corners of the quartz-glass gage and pressed between the surfaces of the gage and 
plate to give the required fringe width. A slight shift of the fringes with pressure was noted, which did not affect the relative measurement of the fringes, however, since no tilting of the fringes was detected. Room temperature was held constant throughout a series of observations. Readings were delayed until the temperature difference between bath and gage had remained constant for 2 hours. Actual procedure was as follows:

The chamber was evacuated at 8:30 a.m. and brought to the required temperature. Differential temperature measurements were begun at 10:10 a.m. and continued until fringe measurements were made at 12:50 p.m. Air was admitted to the chamber at 1:00 p.m., which resulted in a slight increase in the temperature of the gage. To hasten equilibrium, the temperature of the bath was reduced $0.1^{\circ} \mathrm{C}$ for 20 minutes. Couple readings were begun at 1:30 p.m. and continued until fringe measurements and barometric readings were recorded at 3:40 p.m. Table 5 shows the constancy of the thermal conditions.

TABLE 5.-Relative temperature of bath and gage for"ardetermination of $C_{Q}-C_{S}$

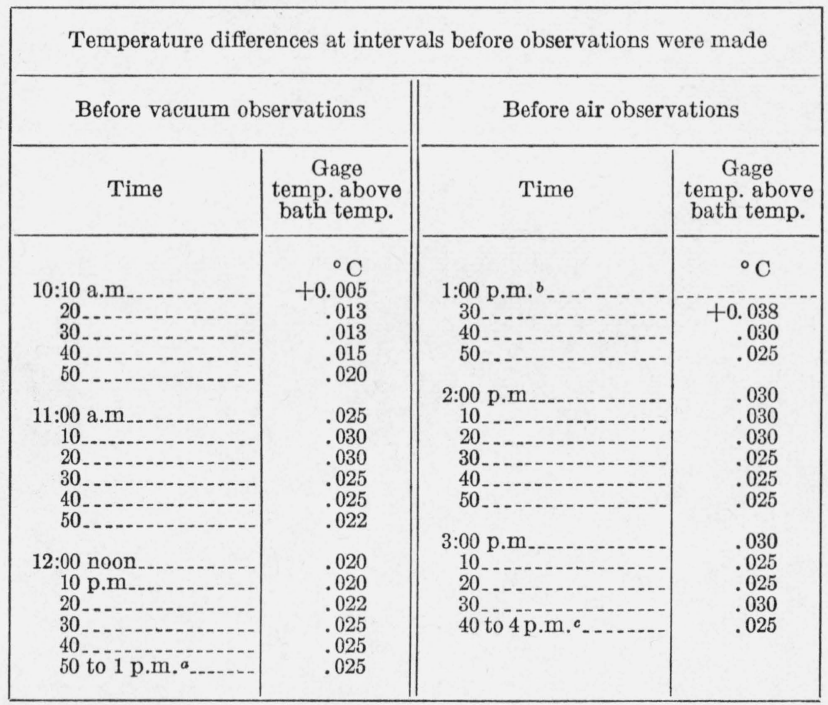

a Readings made for vacuum.

b Air admitted and temperature of bath lowered $0.1^{\circ} \mathrm{C}$ for 20 minutes.

- Readings made for air.

Four series of measurements were made for pressure changes from air to vacuum and one series for a change from vacuum to air. Measurements were made on two adjacent fringes on the steel relative to two opposite fringes on the fused quartz. Differences between measurements of the two fringes were negligible, except for one series in which a difference of 0.038 fringe indicated that the observer may have changed his criterion for estimating the center of the fringe. In this case the mean value was used. Correction to fringe shift because of change of wave length with air density was negligible for the small difference in length of the gages. 
Determinations (see table 6 ) for the five series varied from $C_{Q}-C_{S}=$ $5.6 \times 10^{-7}$ to $7.3 \times 10^{-7}$. The mean difference was

$$
C_{Q}-C_{S}=6.6 \times 10^{-7}
$$

Value $C_{Q}-C_{S}=5.6 \times 10^{-7}$ for series 4 appears somewhat out of line with the other determinations. This low value could have resulted either from a slight tilting of the fringes, which escaped detection, or from an increase of the gage temperature of $0.01^{\circ} \mathrm{C}$. Omission of this result would increase the mean value to $C_{Q}-C_{S}=6.9 \times 10^{-7}$.

These measured differences of the coefficients of compressibility agree favorably with the difference $C_{Q}-C_{S}=9.9 \times 10^{-7}-3.1 \times 10^{-7}=$ $6.8 \times 10^{-7}$, which was derived from direct compressibility determinations. 
TABLE 6.-Measured differences in compressibility of fused-quartz and steel gages

\begin{tabular}{|c|c|c|c|c|c|c|c|c|c|c|c|c|c|}
\hline \multirow{3}{*}{$\begin{array}{l}\text { Tempera- } \\
\text { ture }\end{array}$} & \multirow{3}{*}{$\Delta P$} & \multicolumn{2}{|c|}{ Measured shift } & \multirow{3}{*}{$\Delta L(G, G)^{\mathrm{s}}$} & \multirow{3}{*}{$\begin{array}{c}\text { Index at } \\
\text { measured } \\
\text { tempera- } \\
\text { ture and } \\
\text { pressure }\end{array}$} & \multirow{3}{*}{$\begin{array}{c}\text { Order in } \\
\text { vacuum } \\
\text { (for } \lambda= \\
5877.243 \mathrm{~A} \text { ) }\end{array}$} & \multirow{3}{*}{$\begin{array}{l}\text { Shift } \\
\text { result- } \\
\text { ing } \\
\text { from } \\
\Delta \lambda\end{array}$} & \multicolumn{4}{|c|}{$\begin{array}{l}\text { Total relative change in length } \\
\text { of gages at measured temperature }\end{array}$} & \multirow{3}{*}{$\begin{array}{l}\text { Differ- } \\
\text { ence of } \\
\text { coeff- } \\
\text { cients } \\
C_{Q}-C_{S}\end{array}$} & \multirow{3}{*}{ Time elapsed before observations were made } \\
\hline & & & & & & & & \multirow{2}{*}{$\begin{array}{c}\text { For } \Delta P \\
\text { Air- } \\
\text { vac- } \\
\text { uum } \\
\text { and } \\
\text { vac- } \\
\text { uum- } \\
\text { air }\end{array}$} & \multicolumn{3}{|c|}{ For $760 \mathrm{~mm}$} & & \\
\hline & & $\begin{array}{c}\text { Air- } \\
\text { vacuum }\end{array}$ & $\begin{array}{l}\text { Vac- } \\
\text { uum- } \\
\text { air }\end{array}$ & & & & & & $\begin{array}{l}\text { Air- } \\
\text { vac- } \\
\text { uum } \\
\text { and } \\
\text { vac- } \\
\text { uum- } \\
\text { air }\end{array}$ & $\begin{array}{l}\text { Air- } \\
\text { vac- } \\
\text { uum }\end{array}$ & $\begin{array}{l}\text { Vac- } \\
\text { uum- } \\
\text { air }\end{array}$ & & \\
\hline${ }^{\circ} \mathrm{C}$ & $\begin{array}{l}\mathrm{mm} \\
749.5\end{array}$ & $\left\{\begin{array}{r}\text { Fringe } \\
\text { b } 0.212 \\
\mathrm{c} .218 \\
\end{array}\right.$ & \begin{tabular}{c} 
Fringe \\
\hdashline \\
\hdashline
\end{tabular} & \begin{tabular}{c}
$\mu$ \\
\hdashline \\
\hdashline \\
\end{tabular} & $(n-1) \times 10^{7}$ & & \begin{tabular}{|l} 
Fringe \\
\hdashline-1
\end{tabular} & Fringe & Fringe & \begin{tabular}{c}
$\mu$ \\
\hdashline \\
\hdashline
\end{tabular} & \begin{tabular}{c|c}
$\mu$ \\
\hdashline \\
\hdashline
\end{tabular} & -1 & \}$_{\text {vacuum observations. }}^{240 \text { minutes before air observations; } 180 \text { minutes before }}$ \\
\hline Mean.-- & - & 0.215 & -.......... & 1.41 & 2696 & 4.8 & 0.001 & 0.216 & 0.219 & 0.0643 & - & $6.4 \times 10^{-7}$ & \\
\hline $19.25 \ldots . . .$. & 754.6 & $\left\{\begin{array}{r}b \\
0.223 \\
0.222\end{array}\right.$ & & & & & & & & & & & $\left\{\begin{array}{l}\text { Constant } 135 \text { minutes before air observations; waited } \\
165 \text { minutes, constant } 110 \text { minutes before vacuum } \\
\text { observations. }\end{array}\right.$ \\
\hline Mean... & - & 0.223 & $\ldots$ & 0.49 & 2708 & 1.7 & 0.000 & 0.223 & 0.225 & 0.0661 & -........ & 6.6 & \\
\hline $18.80 \ldots . . . .$. & 751.8 & $\left\{\begin{array}{r}b \\
0.262 \\
0.224\end{array}\right.$ & 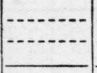 & & & & & & & & & & $\left\{\begin{array}{l}\text { Waited } 150 \text { minutes, constant } 80 \text { minutes before air } \\
\text { observations; waited } 280 \text { minutes, constant } 240 \\
\text { minutes before vacuum observations. }\end{array}\right.$ \\
\hline Mean... & - & 0.243 & -.......... & 0.94 & 2702 & 3.2 & 0.001 & 0.244 & 0.247 & 0.0726 & -....... & 7.3 & \\
\hline 19.50 & 757.6 & $\left\{\begin{array}{r}b \\
0.189 \\
0.189\end{array}\right.$ & $\mid--1-1$ & $(-2)$ & $\cdots$ & & ( & $\mid-\cdots-1$ & & & & & $\left\{\begin{array}{l}\text { Waited } 260^{*} \text { minutes, constant } 240 \text { minutes before air } \\
\text { observations; waited } 260 \text { minutes, constant } 120 \\
\text { minutes before vacuum observations. }\end{array}\right.$ \\
\hline Mean.-- & - & 0.189 & - & 0.25 & 2715 & 0.8 & 0.000 & 0.189 & 0.190 & 0.0558 & -........ & 5.6 & \\
\hline $19.00 \ldots . . .$. & 745.4 & $\left\{\begin{array}{l}\{-1-\cdots \\
\hdashline-\cdots-\cdots\end{array}\right.$ & $\begin{array}{r}\text { a } 0.238 \\
\text { b. } 238\end{array}$ & 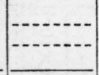 & - & - n- & $-\cdots-1$ & 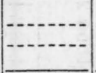 & - & & & & $\left\{\begin{array}{l}\text { Waited } 260 \text { minutes, constant } 170 \text { minutes before } \\
\text { vacuum observations; waited } 160 \text { minutes, constant } \\
120 \text { minutes before air observations. }\end{array}\right.$ \\
\hline Mean_-.- & - & $\ldots$ & 0.238 & 0.73 & 2677 & 2.5 & 0.001 & 0.239 & 0.244 & -......... & 0.0717 & 7.2 & \\
\hline Mean.-- & & - & & & & & & 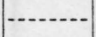 & - & - n & $\ldots$ & $6.6 \times 10^{-7}$ & \\
\hline
\end{tabular}




\section{SUMMARY OF RESULTS}

The values for all of the compressibility determinations are summarized in table 7. By the direct method of determination (columns 1 and 2), in which identical materials were used and in which temperature uncertainties least affected the results, maximum differences of individual determinations were $4 \times 10^{-8}$ for fused quartz and $6 \times 10^{-8}$ for steel; maximum variations from mean values were $2 \times 10^{-8}$ and $4 \times 10^{-8}$, respectively. The coefficients of longitudinal compressibilities determined by this method were

$$
\begin{aligned}
C_{Q} & =9.9 \times 10^{-7} \text { per atmosphere. } \\
C_{S} & =3.1 \times 10^{-7} \text { per atmosphere; or } \\
C_{Q}-C_{s} & =6.8 \times 10^{-7} .
\end{aligned}
$$

The difference of coefficients (column 3 ) determined by comparison of a fused-quartz gage and a steel gage was $C_{Q}-C_{s}=6.6 \times 10^{-7}$ per atmosphere. This determination is in good agreement with the difference derived by the direct method.

Substitution of the above values for $C_{Q}$ and $C_{s}$ in the comparative determinations by methods 1 and 3 (columns 4 to 9 ) gave consistent agreement for derived values. This agreement extended to those determinations (columns 6 and 9) in which experimental uncertainties had greatest effect upon results. Maximum variation of the mean of any comparative determination from the values of $C_{0}$ and $C_{s}$, which were determined directly, was $2 \times 10^{-8}$ for fused quartz and $4 \times 10^{-8}$ for

\begin{tabular}{|c|c|c|c|c|c|c|c|c|c|}
\hline \multirow{5}{*}{$\begin{array}{l}\text { Compress- } \\
\text { ibility }\end{array}$} & \multicolumn{2}{|c|}{ Method 2.-Direct } & \multirow{2}{*}{\multicolumn{3}{|c|}{$\begin{array}{l}\text { Method 1.-Comparison of } \\
\text { gages of dissimilar materials }\end{array}$}} & \multicolumn{4}{|c|}{$\begin{array}{l}\text { Method 3.-Comparison of tube and } \\
\text { gage of dissimilar materials }\end{array}$} \\
\hline & \multirow{3}{*}{$\begin{array}{c}\text { Steel tube } \\
\text { and steel } \\
\text { gage }\end{array}$} & \multirow{3}{*}{$\begin{array}{c}\text { Quartz } \\
\text { tube and } \\
\text { quartz } \\
\text { gage }\end{array}$} & & & & $\begin{array}{l}\text { Steel tu } \\
\text { quart }\end{array}$ & $\begin{array}{l}\text { ube and } \\
\text { tz gage }\end{array}$ & $\begin{array}{l}\text { Quartz } t \\
\text { steel }\end{array}$ & $\begin{array}{l}\text { be and } \\
\text { age }\end{array}$ \\
\hline & & & \multirow[b]{2}{*}{ Measured } & \multicolumn{2}{|c|}{$\begin{array}{l}\text { Computed from } \\
\text { column } 3 \text { values }\end{array}$} & \multirow{2}{*}{$\begin{array}{c}\text { Assume } \\
C s= \\
3.1 \times 10^{-7}\end{array}$} & \multirow{2}{*}{$\begin{array}{c}\text { Assume } \\
C_{Q=}= \\
9.9 \times 10^{-7}\end{array}$} & \multirow{2}{*}{$\begin{array}{c}\text { Assume } \\
C 8= \\
3.1 \times 10^{-7}\end{array}$} & \multirow{2}{*}{$\begin{array}{c}\text { Assume } \\
C_{Q}= \\
9.9 \times 10^{-7}\end{array}$} \\
\hline & & & & $\begin{array}{c}\text { Assume } \\
C s= \\
3.1 \times 10^{-7}\end{array}$ & $\begin{array}{c}\text { Assume } \\
C_{Q}= \\
9.9 \times 10^{-7}\end{array}$ & & & & \\
\hline & 1 & 2 & 3 & 4 & 5 & 6 & 7 & 8 & 9 \\
\hline \multirow{2}{*}{ Mean... } & $\left\{\begin{array}{l}3.2 \times 10^{-7} \\
3.3 \\
2.7 \\
3.3 \\
-\cdots---\end{array}\right.$ & 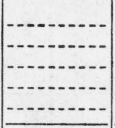 & 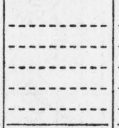 & 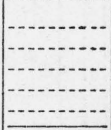 & $\begin{array}{l}3.5 \times 10^{-7} \\
3.3 \\
2.6 \\
4.3 \\
2.7 \\
\end{array}$ & 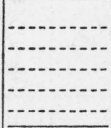 & $\begin{array}{l}2.8 \times 10^{-7} \\
3.1 \\
3.2 \\
-\end{array}$ & 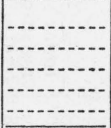 & $\begin{array}{l}2.6 \times 10^{-7} \\
2.8+ \\
-\end{array}$ \\
\hline & $3.1 \times 10^{-7}$ & $\mid$ & & - & $3.3 \times 10^{-7}$ & - n........ & $3.0 \times 10^{-7}$ & & $2.7 \times 10^{-7}$ \\
\hline \multirow{2}{*}{ Mean... } & 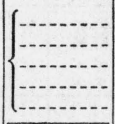 & $\begin{array}{c}9.9 \times 10^{-7} \\
9.7 \\
10.0 \\
10.1 \\
9.8\end{array}$ & 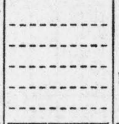 & $\begin{array}{c}9.5 \times 10^{-7} \\
9.7 \\
10.4 \\
\text { b } 8.7 \\
10.3\end{array}$ & 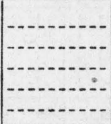 & $\begin{array}{l}10.5 \times 10^{-7} \\
9.8 \\
9.8\end{array}$ & 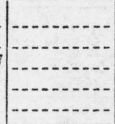 & $10.2 \times 10^{-7}$ & 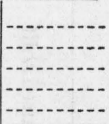 \\
\hline & & $9.9 \times 10^{-7}$ & & $9.7 \times 10^{-7}$ & & $10.0 \times 10^{-7}$ & & $10.1 \times 10^{-7}$ & \\
\hline \multirow[t]{2}{*}{$\mathrm{C}_{\mathbf{Q}}-\mathrm{Cs}_{\ldots}$} & & 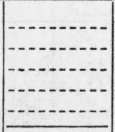 & $\begin{array}{l}6.4 \times 10^{-7} \\
6.6 \\
7.3 \\
* 5.6 \\
7.2 \\
\end{array}$ & 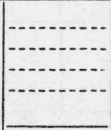 & \begin{tabular}{l}
$-\cdots$ \\
\hdashline-1 \\
\hdashline$-n$ \\
\hdashline$-n$ \\
\end{tabular} & $-\ldots$ & $\ldots$ & 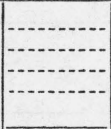 & 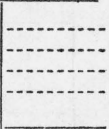 \\
\hline & & & $6.6 \times 10^{-7}$ & & & & & & \\
\hline
\end{tabular}
steel.

TABLE 7.-Summary of compressibility determinations for fused quartz and steel

a Uncertainties should be greater by this method of determination.

b Values resulting from*, column 3 . 


\section{DISCUSSION OF RESULTS}

The determined value, $C_{Q}=9.9 \times 10^{-7}$, agrees with that of Adams, Williamson, and Johnston, extrapolated to atmospheric pressure from pressures of 2,000 to 10,000 atmospheres, whereas the determined value $C_{S}=3.1 \times 10^{-7}$, is 50 percent greater than any measured values we have been able to locate on ferrous alloys ranging from 0.03 percent of other elements through ordinary low- and high-carbon steels, both annealed and quenched, and including a "stainless iron" containing about 16 percent of chromium and about 8 percent of nickel. These values are partly from published reports ${ }^{910} 1112$ and partly from unpublished data of Dr. L. H. Adams, which he was kind enough to supply. Since all these values are based upon measurements made at pressures of many atmospheres, it is conceivable that determinations at lower pressures might show a divergence from the straight line relationship for steel. By extrapolation of their curves, Adams, Williamson, and Johnston derived compressibilities 2 to 22 percent greater at 1 atmosphere than at 10,000 atmospheres for certain materials. It is also possible, in view of the known fact that Young's modulus of high-alloy steels may differ by 20 percent from the value of plain carbon steels, that the compressibility of the 14-percent chromium steel used in this investigation may actually be considerably higher at all pressures than that for carbon steels. The 14-percent chromium steel was chosen because it is particularly free from changes of dimension during heat-treatment. This quality is generally associated with good isotropy of the material after heat treatment but the marked anisotropy of a heat-treated chrome-vanadium steel cylinder reported by Bridgman raised the question of possible anisotropy in the steel gage and tube. However, metallographic examination of sections of the steel in both the longitudinal and transverse directions gave no evidence of selective orientation of the crystals. In any case, the analysis of section II of this paper shows that no error would arise from the possibility of transverse anisotropy, as long as the axial elastic constants of the tube and the gage were identical. This seems a reasonable presumption, since both were given identical heat-treatment.

The only other suspected source of appreciable error in the work is that due to faulty wringing. For the fused-quartz tube and gages, no separation of surfaces was of sufficient magnitude to affect results. The wringing of the steel gage and of the steel tube was less satisfactory. Any error from this source would result in a greater change of length between plate and gage surfaces for a change of pressure than that due to compressibility. Furthermore there were two wrung surfaces between the tube and plates, and each had an area of contact of only half the external cross-sectional area of the tube, so that the manner of use of the tube would increase any error due to compression of wrung surfaces. The total movement in any case would appear attributable to compressibility and the results of comparative measurements of steel and fused quartz would be high $C_{S}$ values.

It was originally intended to assume $C_{S}=2.0 \times 10^{-7}$, the value cited in the literature, and from this value, to derive $C_{Q}$ from comparative

- Bridgman, Proc. Am. Acad. Arts Sci. 58, 169-174, (1923).

10 Adams, Williamson, and Johnston, J. Am. Chem. Soc. 41, 12-42 (1919).

11 Grüneisen, Ann. Physik 33, 1239 (1910).

12 Richards, J. Am. Chem. Soc. 37, 1643 (1915). 
measurements. Substitution of this value in all comparative determinations of tubes and gages gives less consistent agreements of $C_{Q}$ values (table 8, column 2) than does the use of $C_{S}=3.1 \times 10^{-7}$ (column 1) which was derived by direct measurement. To duplicate the latter agreement with an assigned value $C_{S}=2.0 \times 10^{-7}$ (column 3 ), would require an added change of length attributable to change of distance between surfaces of $0.022 \mu$ (0.075 fringe) for the steel tube and $0.011 \mu$ (0.038 fringe) for the steel gage at all times and for all wringings of the steel gage. Probability of this accidental relationship of errors of wringing or of an exceptionally high $C_{S}$ for this stainless steel is vitiated to some extent by the result of direct comparison of the stainless-steel gage with the two Johansson steel gages used in the preliminary investigation. This comparison gave a somewhat greater compressibility for the Johansson gages which fall definitely into the class of plain-carbon steels for which the longitudinal compressibility is $2.0 \times 10^{-7}$ at high pressures. If the correction for the wringing of the stainless-steel gage is negligible, no correction for an error in wringing of the steel tube may be applied which will bring the results of all measurements into the excellent agreement of column 1 without added assumptions which at present appear unwarranted. The measurements, therefore, seem to indicate that the compressibilities of steels in general are considerably greater in the range from 0 to 1 atmosphere pressure than at the higher pressures of many atmospheres at which they have previously been measured. Further measurements would be necessary to establish this definitely.

TABLE 8.- $C_{Q}$ values from comparative determinations; with and without assumed corrections for wringing

\begin{tabular}{|c|c|c|c|}
\hline \multirow{3}{*}{ Tubes and gages compared } & \multicolumn{3}{|c|}{$\begin{array}{l}\text { Coefficient of longitudinal compressibility, } \\
\qquad C_{Q}\end{array}$} \\
\hline & \multirow[b]{2}{*}{$\begin{array}{c}\text { (Assuming } \\
\left.C_{S}=3.1 \times 10^{-7}\right) \\
\text { No correc- } \\
\text { tion for } \\
\text { wringing } \\
\text { (1) }\end{array}$} & \multicolumn{2}{|c|}{ (Assuming $C_{S}=2.0 \times 10^{-7}$ ) } \\
\hline & & $\begin{array}{l}\text { No correction } \\
\text { for wringing } \\
\text { (2) }\end{array}$ & $\begin{array}{c}\text { Corrections } \\
\text { for wringing: } \\
\text { Steel tube= } \\
.022 \mu \\
\text { Steel gage = } \\
.011 \mu \\
\text { (3) }\end{array}$ \\
\hline $\begin{array}{l}\text { Quartz gage and steel gage } \\
\text { Quartz tube and steel gage } \\
\text { Steel tube and quartz gage }\end{array}$ & $\begin{array}{l}9.7 \times 10^{-7} \\
10.1 \\
10.0\end{array}$ & $\begin{array}{l}8.6 \times 10^{-7} \\
9.6 \\
7.8\end{array}$ & $\begin{array}{l}9.7 \times 10^{-7} \\
10.1 \\
10.0\end{array}$ \\
\hline Mean & $9.9 \times 10^{-7}$ & $8.7 \times 10^{-7}$ & $9.9 \times 10^{-7}$ \\
\hline rtz gage by c & t compariso & $C_{Q}=9.9 \times 10^{-7}$ & \\
\hline
\end{tabular}

With polished steel surfaces of the required planeness to avoid uncertainties here encountered, it is believed that the methods used in this investigation are sufficiently accurate to establish $C_{S}$. Greater accuracy of both $C_{S}$ and $C_{Q}$ determinations may be attained by increasing the length of specimens and by decreasing wall thicknesses of tubes to the minimum required for wringing. Combination of data resulting from measurements with new apparatus, which permits extension of determinations to 10 atmospheres, with those from meas- 
urements of the same material at high pressures by the method of Adams, Williamson, and Johnston, would more definitely establish the $(P-\Delta V)$ relationship from 0 to 12,000 atmospheres.

\section{CONCLUSIONS}

Fused-quartz glass.- The longitudinal compressibility of clear, annealed fused quartz for a pressure of 1 atmosphere was determined to be $9.9 \times 10^{-7}$, or

$$
C_{Q}=9.9 \times 10^{-7} \pm 5 \times 10^{-8} \text { per atmosphere. }
$$

Equivalent values are

Coefficient of longitudinal compressibility per megabar..- $9.8 \times 10^{-7}$. Bulk compressibility per megabar, $k$..........

Steel.-The longitudinal compressibility of a heat-treated 14-percent chromium steel for a pressure of 1 atmosphere was determined to be $3.1 \times 10^{-7}$ or

$$
C_{S}=3.1 \times 10^{-7} \text { per atmosphere. }
$$

Equivalent values are

Coefficient of longitudinal compressibility per megabar-_- $3.1 \times 10^{-7}$. Bulk compressibility per megabar, $k \ldots \ldots \ldots \ldots 10^{-7}$.

For the reasons discussed in section VI, no limit of accuracy can be assigned to these values for steel.

The author expresses his appreciation to F. C. Roop for assistance in revising the manuscript and in checking the validity of the application of the formulas used.

Washington, February 20, 1937. 